\title{
Economic Growth and Infrastructure Expenditure in Kenya: A Granger-Causality Approach
}

\author{
Samuel Chingoiro ${ }^{1} \&$ Strike Mbulawa $^{2}$ \\ ${ }^{1}$ Faculty of Business and Accountancy, Botho University, Gaborone, Botswana. Tel: +267 71767364 \\ ${ }^{2}$ Faculty of Business and Accountancy, Botho University, Gaborone, Botswana. Tel: +267 74052456 \\ Correspondence: Samuel Chingoiro, Faculty of Business and Accountancy, Botho University, Gaborone, Botswana.
}

Received: June 3, 2016

doi:10.11114/ijsss.v4i9.1749
Accepted: June 16, $2016 \quad$ Available online: July 18, 2016

URL: http://dx.doi.org/10.11114/ijsss.v4i9.1749

\begin{abstract}
The President of Kenya, in January 2014, announced that infrastructure development would be used as the major drive to achieve economic growth during the tenure of his presidency. A notable part of the statement by the President is the requirement that the policy would involve very significant public expenditure on infrastructure. In that context, this study undertook a causality analysis between infrastructure expenditure and economic growth and labor was introduced into the framework as a control variable. The study also undertook to establish if innovations in one variable would influence the future behavior of another. Annual data used in this study was obtained from World Development Indicators for the period 1980 to 2013. Using Granger Causality approach the study reveals that: there is bidirectional flow of causality between economic growth and infrastructure, shocks in economic growth explained the behavior of infrastructure even beyond eight years, and that infrastructure expenditure is explained by innovations in the previous period. The findings suggest that the government should commit more funds towards developing infrastructure in the short term. This should be complemented by improving the quality of institutions and an improvement in the level of regulation to enhance sustainable growth.
\end{abstract}

Keywords: Economic Growth, Infrastructure, Kenya, Causality

\section{Introduction}

The relationship between infrastructure expenditure and economic growth is generally not easy to establish. This is so because the causality between the two variables is not simple to empirically determine (Sutherland et al, 2009). It is difficult to verify with precision the effect of infrastructure projects has had on economic growth, as it is hard to disentangle these from other development expenditure that occur simultaneously in the economy. Also, the point in time when infrastructure investment begins to yield results to the economy and the lasting period are difficult to tell (Congressional Budget Office, 2015). However, literature has acknowledged the positive role played by infrastructure investment in pursuit of growth (Fedderke et al, 2006 and Sahoo and Dash, 2009). First, investment in infrastructure has a direct effect on promoting facilities that are conducive for productive activities. Transactional and transportation costs generally decrease as more physical infrastructure is developed (Ansari et al, 2010). Secondly, employment is created during construction of the infrastructure and more opportunities can be availed to the poor in the process.

The problem of adequate infrastructure is common in countries at different levels of development, particularly in Africa. Evidence (Gutman et al, 2015) shows that Sun Saharan Africa (SSA) still lack infrastructure to support development initiatives. In their view they postulated that infrastructure development in Africa is potentially transformational in terms of working towards sustained economic growth and development. The Africa Development Bank (AfDB) (2013) stated that despite Africa's wealthy mineral resources, the continent ranks at the bottom of the productivity ladder due to inadequacy of infrastructure. The World Bank (2011) estimated that SSA needs US\$93 billion annually, based on the region's 2009 state of affairs, in order to close the infrastructure gap. This is further confirmed by the World Economic Forum (2012) which asserts that Africa has continued to languish at the bottom of the competitive global ranking partly because of infrastructure shortcomings.

In response to the infrastructure status in Africa, the G20 has been weighing in with their support to help bolster infrastructure in the region and the AfDB has taken the responsibility of developing an index for infrastructure development in Africa called the AIDI. This is used to trace the progress of advancement of the infrastructure on annual 
basis. The current AIDI covers the infrastructure status for the 2000 to 2010 period. Top ten African countries according to the rankings of this index as of 2010 included Seychelles at the top, followed by South Africa, Egypt, Libya and Mauritius. Kenya is ranked number 23rd out of the 53 African countries. However, the AfDB (2013) has recognized Kenya, Ghana and Senegal as high performing African countries that have significantly improved on their individual infrastructure index. Kenya improved from a ranking position of $35^{\text {th }}$ to a $23^{\text {rd }}$ in year 2000 and 2010 respectively. The country has channeled almost 27 percent of its national budget over the past five years towards infrastructure (AfDB, 2014). Despite this commitment, the country's medium term plan (11) has indicated that an annual expenditure of US $\$ 4$ billion is required if the country is to resolve the current insufficiency in its infrastructure. Figure 1 below, indicates the country's infrastructure development ranking in Africa as indicated by road, rail and ports. The figure shows that, though the country needs to inject more effort to cover its infrastructure gap as it lags behind several countries in Africa, Kenya is considered the biggest economy in the East African region. In the year ending 2014, Kenya's GDP at current price amounted to US\$60.9 billion compared to US\$49.2 billion and US\$26.3 billion for Tanzania and Uganda respectively. In a country-strategy paper covering the period beginning the year of 2014 to the end of 2018, the AfDB (2014) stated that Kenya is amongst the fastest growing African economies, but is grappling with infrastructure deficits.

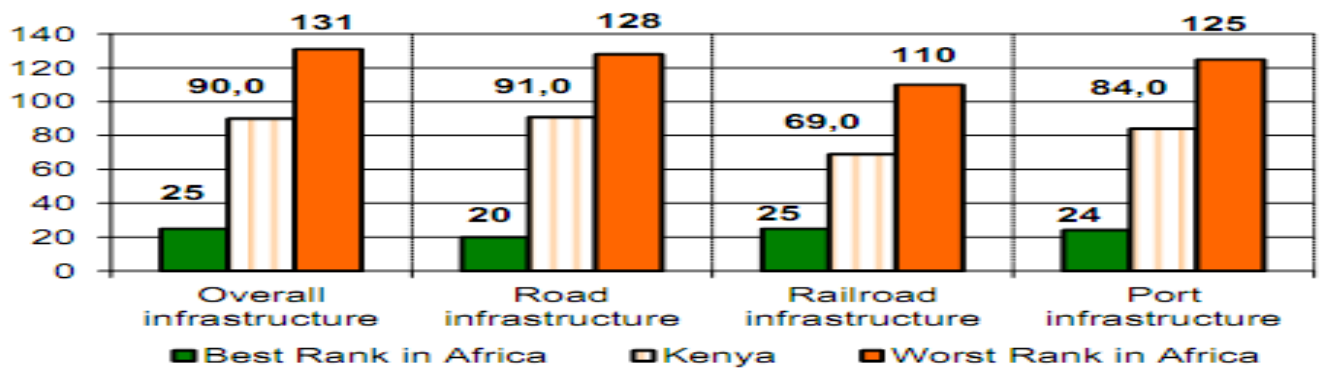

Source: AfDB (2014)

Figure 1. Africa Development Index, 2011

Kenya's commitment towards investing on infrastructure can be viewed from the perspective of positive growth rates on its Gross Domestic Fixed Capital Formation (to be abbreviated as GDFCF hereafter) over the past five years ending 2014. For the same period, the country has also posted positive growth rates in GDP. A closer look at these two annual growth rates has shown a weak positive correlation of 20.1 percent (See Table 1).

Table 1. Correlation Matrix between GDPgr and GDFCF

\begin{tabular}{ccc}
\hline & GDPgr & GDFCF \\
\hline GDPgr & 1 & 0.20 \\
GDFCF & 0.20 & 1 \\
\hline
\end{tabular}

This positive correlation does not imply causation but it may indicate some degree of association between economic growth and investments in the physical infrastructure (see Figure 2).



Figure 2. Kenya's Growth rates of GDP and GDFCF (2005-2014)

Source: World Development Indicators (2015)

Figure 2 shows the line graph of the two growth rates that seem to move in the same direction in an unclear pattern. The relationship between economic growth and infrastructural development is not clear and there is no evidence on the direction of causality. We argue in this paper that knowing the direction of causality is critical for policy makers to 
develop credible and sustainable strategies for growth. We also argue that understanding the relationship between infrastructure and economic growth is important in the context of Kenya considering the need to close the country's infrastructural gap. The political leadership has recognized the significance of attaining sustainable economic growth of which infrastructural development has potential to make a significant contribution. It is also important to determine the timeframe within which investment in infrastructure should be made failure of which produces adverse results.

The main objective of this paper is to determine the direction of causality between economic growth and infrastructural development. The intention is to contribute to the existing debate on the direction of causality between the two variables which remains inconclusive in literature. The study used granger causality tests to examine the link between the two variables. We also tested the level of sensitivity of economic growth to innovations in infrastructural development. This was further supported by testing whether or not later drives the economic growth and vice versa. Evidence in this study supports earlier findings in literature of bidirectional causality between economic growth and infrastructure. Infrastructure movements in the current period are explained by its own shocks as well as shocks in economic growth in the previous period.

The rest of the paper is organized as follows: section two examines both theoretical and empirical evidence on economic growth and infrastructural development. Section 3 describes the data and the empirical methodology employed in this study. Section 4 presents empirical findings. Section 5 concludes and gives policy direction.

\section{Review of Literature}

\subsection{Theoretical Review}

The quality of infrastructure matters for economic development as it can reduce costs, promotes integration, factor mobility and the country can take advantage of opportunities for investment in human capital. The endogenous growth model, by Barro (1990), shows that the flow of productive expenditure by the government contributes to the level of current production for the entire economy. The production function framework has been used to explain the connection between investment and economic growth. Infrastructure can be included as an additional factor of production by incorporating it in the neoclassical growth model. Factors of production are captured well by the general Cobb Douglas function (Sahoo et al, 2010 and Nedozi et al, 2014) which can be shown as

$$
Y_{t}=f(K, L, \text { Infrastr })
$$

Model (1) shows that economic growth, $Y_{t}$, is a dependent on the level of capital, $K$, labour force, $L$, and the level of expenditure on infrastructure, Infrastr.

Infrastructure can have a long run effect on economic growth which is subject to the model of growth, neoclassical or endogenous, employed in generating data. According to the exogenous growth model shocks to infrastructure are perceived to have only transitory effects on growth which is only true in cases where long term growth is driven by technical progress. The endogenous growth model argues that any shocks to infrastructure have an effect of increasing the steady-state level of output (Lucas, 1988, Barro, 1990).

\subsection{Empirical Review}

The importance of infrastructure development in enhancing economic growth cannot be underestimated. The debate on the connection between economic growth and infrastructure is still far from over. Empirical work that examines the relationship between economic performance and infrastructure investment dates back to 1989, when Aschauer presented his seminal paper on how infrastructure investment impacted factor productivity in the United States (Sahoo and Dash, 2009 and Serven, 2010). The time series results obtained showed that public investments in infrastructure significantly impacts positively on labor productivity. Subsequent researches in this area have employed different data methodologies ranging from reduced-form models of growth, cross country and panel data econometric modeling. A borne of contention in the application of these different methodologies has been comparability of the research findings. Some econometricians have argued against the technicalities surrounding certain methodologies used in some studies including issues of unresolved endogeneity, stationarity of variables, choice of functional forms used in the models, and so on (Estache and Garsous, 2012).

However, most of these studies have demonstrated the positive effect of infrastructure on the economy (Sahin et al, 2014, Owolabi, 2015, Fedderke and Garlick, 2008). Calderon and Serven (2008) view the supply of infrastructure services as being necessary for growth. Their paper assesses the impact of infrastructure development on inequality and growth using a panel of 100 countries. They show that quality and quantity of infrastructure has a positive and negative impact on growth and income equality in the long term and short term respectively. Infrastructure helps reduce poverty in the country. This is supported by Ahmed, Abbas and Ahmed (2013) in their study showing that public infrastructure investments positively affect growth and reduce poverty in the long term. Sahoo et al (2010) argue that infrastructure 
stock is not the only key driver for growth but other factors include labor force and investment expenditure. They further show that causality between infrastructure and growth is unidirectional which justify the need to increase expenditure on growth. Infrastructure needs to be supported by human capital formation. Srinivasu and Rao (2013) suggest that expenditure on infrastructure is vital to achieve development targets in the economy as it provides the platform upon which development initiatives bear fruit. In other words infrastructure is a vital precondition for growth thus it plays an indirect role on growth. Babatunde et al (2012) further argues that investment in infrastructure directly affects growth by working through industrial output and indirectly through sectors like manufacturing and oil. Nedozi, Obasanmi and Ighata (2014) suggests that infrastructure is an integral part of growth as it is an intermediate product for the real sector and a finished product from the consumer's point of view.

Studies have failed to agree on the direction of causality for example Kaur and Malhotra (2014) suggest that there is causal relationship moving from telecommunication development to growth. This finding is later dismissed by Owolabi (2015) who found no causal relationship between the two variables. However, Banerjee et al (2012) argue that the proximity to transportation networks has a moderate positive effect on per capita GDP across sectors but it has no effect on per capita GDP growth. A bi-directional causality between the two variables has been confirmed by other researchers as well in literature (Babatunde et al, 2012 and Kumo, 2012).

In assessing whether infrastructure affect economic activity and the magnitude of such an effect, researchers have so far not come to a common ground due to differences in measures of infrastructure (Serven, 2010). Infrastructure is heterogeneous in that it includes societal and economic infrastructures (Stewart, 2010). Societal infrastructure includes roads, dams, hospitals whereas economic infrastructure covers network services and utilities like telecommunications, transportations, water and electricity. One strand of scholars believes in assessing individual type of infrastructure such as the number of telephone lines or the number kilometers of paved roads. The benefit in using such an approach is the possibility of assessing the impact of different types of infrastructure on economic performance. However, the biggest setback in this approach is the unavailability of data. Another strand of researchers has tended to use aggregated data such as public capital as it is readily available (Estache and Garsous, 2012). This study follows the later strand and uses the Gross Domestics Fixed Capital Formation (GDFCF) as the proxy variable for infrastructure, owing to data availability. Although some researchers have argued that public capital tend to underestimate the impact of infrastructure on economic activity, at least such a variable provides a rough and quick way of analysis (Serven, 2010, Estache and Garsous, 2012). The main observation from literature is that there is no agreement on the direction of causality between economic growth and infrastructure, there is no uniformity on the measures used for infrastructure and that studies have used different methodologies. This creates a need to examine the connection between the two variables in the context of Kenya since previous studies failed to give policies that may be generalized across countries.

\section{Methodology and Estimation Procedure}

The data used in estimating the results for this study were obtained from the World Bank (2014). Granger Causality approach (1969) was used to investigate the direction of causality between economic growth and infrastructure development. The approach holds that the time series Infrastr ${ }_{t}$ (the infrastructure variable as represented by the GDFCF annual growth rates) Granger causes a corresponding time series $G D P g r_{t}$ (economic growth as measured by the annual GDP growth rates), if and on if $G_{G D P r_{t}}$ can be estimated better by utilizing past data of both (Infrastr ${ }_{t}$, $G D P g_{t}$ ) as opposed to using only past data of $G D P g r_{t}$ (Green, 2012). Therefore, the causality between economic growth and infrastructure development can be tested by examining their stationary series presented below as a bivariate auto-regression:

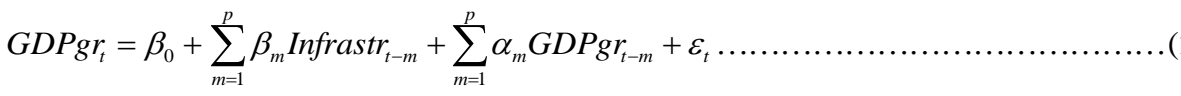

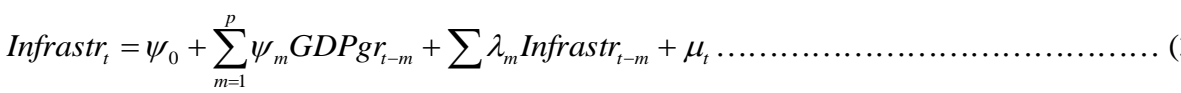

Where $\mathrm{p}$ represent an appropriate time period that allows enough degrees of freedom; $\beta_{m}{ }^{\prime} s$ and $\alpha_{m}{ }^{\prime} s$ for $m=0,1, \ldots \ldots p$ are constants; and $\varepsilon_{t}$ and $\mu_{t}$ are the error terms with zero and finite means and variances respectively. If labor is introduced into the framework as a control variable with respect to the concept by Romer et al (1992) that labor is a necessary input of production (represented by the total number of students enrolled in public and private secondary schools), equations 2 and 3 changes to 4 and 5 respectively as follows: 


$$
\begin{aligned}
& \text { GDPgr }_{t}=\beta_{0}+\sum_{m=1}^{p} \beta_{m} \text { Infrastr }_{t-m}+\sum_{m=1}^{p} \alpha_{m} \text { GDPgr }_{t-m}+\sum_{m=1}^{p} \phi_{m} \text { labor }_{t-m}+\varepsilon_{t} . \\
& \text { Infrastr }_{t}=\psi_{0}+\sum_{m=1}^{p} \psi_{m} \text { GDPgr }_{t-m}+\sum_{m=1}^{p} \lambda_{m} \text { Infrast }_{t-m}+\sum_{m=1}^{p} \phi_{m} \text { labor }_{t-m}+\mu_{t}
\end{aligned}
$$

The null hypothesis for testing the Granger causality is specified by verifying if the coefficients $\beta$ 's and $\psi_{m}$ and $\phi_{m}$ 's are significant, when their respective T-statistic is considered. Before the causality tests are run, it is always necessary to check if the time series variables are stationary. When this procedure was taken, it was found that all the variables were non-stationary. However, after differencing each variable once, they all became stationary (see Table 2).

Table 2. Unit root tests

\begin{tabular}{ccccc}
\hline Variables & \multicolumn{2}{c}{ Levels } & \multicolumn{2}{c}{ First differencing } \\
\hline & Statistic & Probability & Statistic & Probability \\
$\mathrm{GDP}_{\mathrm{gr}}$ & -2.005 & 0.2842 & -3.685 & 0.0043 \\
Infrastr & -2.445 & 0.1295 & -3.196 & 0.0202 \\
\hline
\end{tabular}

The next procedure was to check if the underlying differenced variables were cointegrating. If they cointegrate, it would have been necessary to include an error term into the above framework and a Vector Error Correction Model would be appropriate for undertaking the causality tests. However, the cointegration tests showed that the variables where not cointegrating and thus no long run relationships existed between the variables (see Figure 3). This result, however, contradicts results by Canning and Pedroni (2004) who found strong evidence that infrastructure induce long run growth.

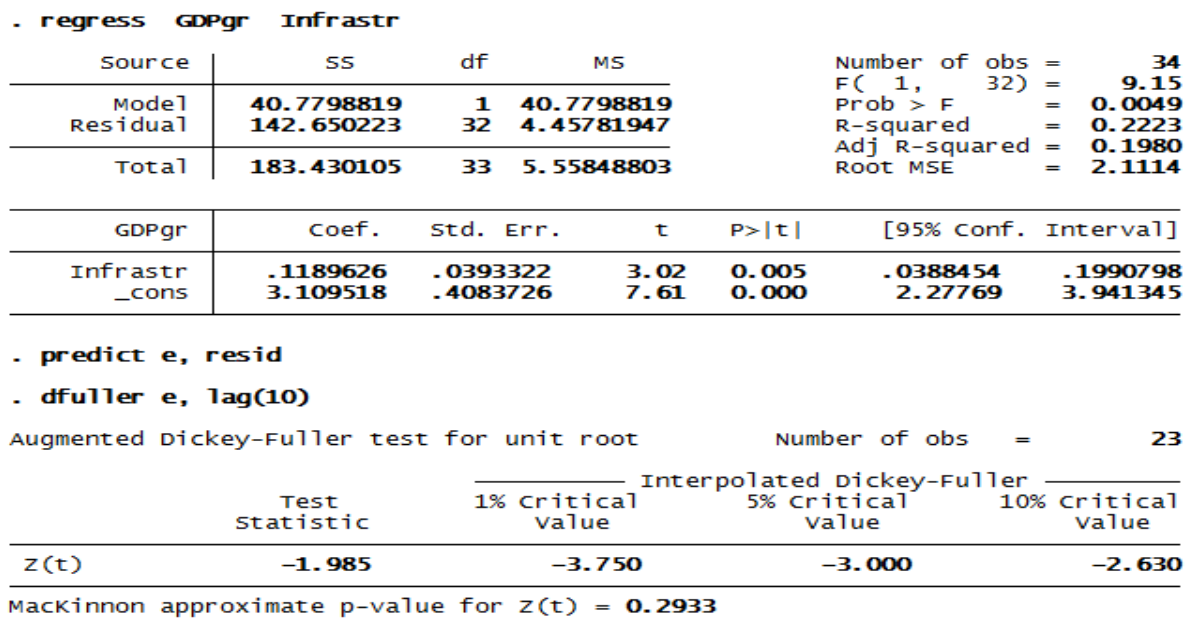

Figure 3. Co-integration test results. No co-integration

\section{Results and Analysis}

The results, Table 3 below, in this study confirm short run relationships since the variables did not integrate, thus absence of a long run relationship. Consequently, it has been found that the both infrastructure development and labor (human capital development) exhibit bi-directional causality relationship with economic growth.

Table 3. Results on Granger Causality

\begin{tabular}{ccc}
\hline Null hypothesis & Z-Statistic & Probability \\
\hline GDP $_{\mathrm{gr}}$ does not Granger cause Infrastr & 2.96 & 0.003 \\
Infrastr does not Granger cause GDP $_{\mathrm{gr}}$ & 2.23 & 0.026 \\
HumanCap does not Granger cause GDP $_{\mathrm{gr}}$ & 1.65 & 0.098 \\
GDP $_{\text {gr }}$ does not Granger Cause Humancap & 2.30 & 0.021
\end{tabular}

Our results are consistent with Shiu and Lam (2007) though their results were based on cross country data. Findings in our study show that expenditure and/or development in infrastructure has potential to bring about economic growth in Kenya. It is also evident in this study that as the economy grows the country would also expand its infrastructure to support the growth process. Focusing on economic growth with no immediate address of the investment in infrastructure may cause growth efforts to fail to pay dividends. The results are consistent most of the empirical findings 
in the literature that infrastructure development generally impacts positively on economic activity. A notable example is a study by Aschauer (1989), which found that public expenditure on infrastructure raised factor productivity in the US. Other researchers that found positive results are Bom and Light (2009) and Loayza and Odawara (2010) among others. The study also used impulse response function (IRF) to examine the extent to which economic growth would explain movements in infrastructure and vice versa. The graph for IRF is presented in Figure 4 below.

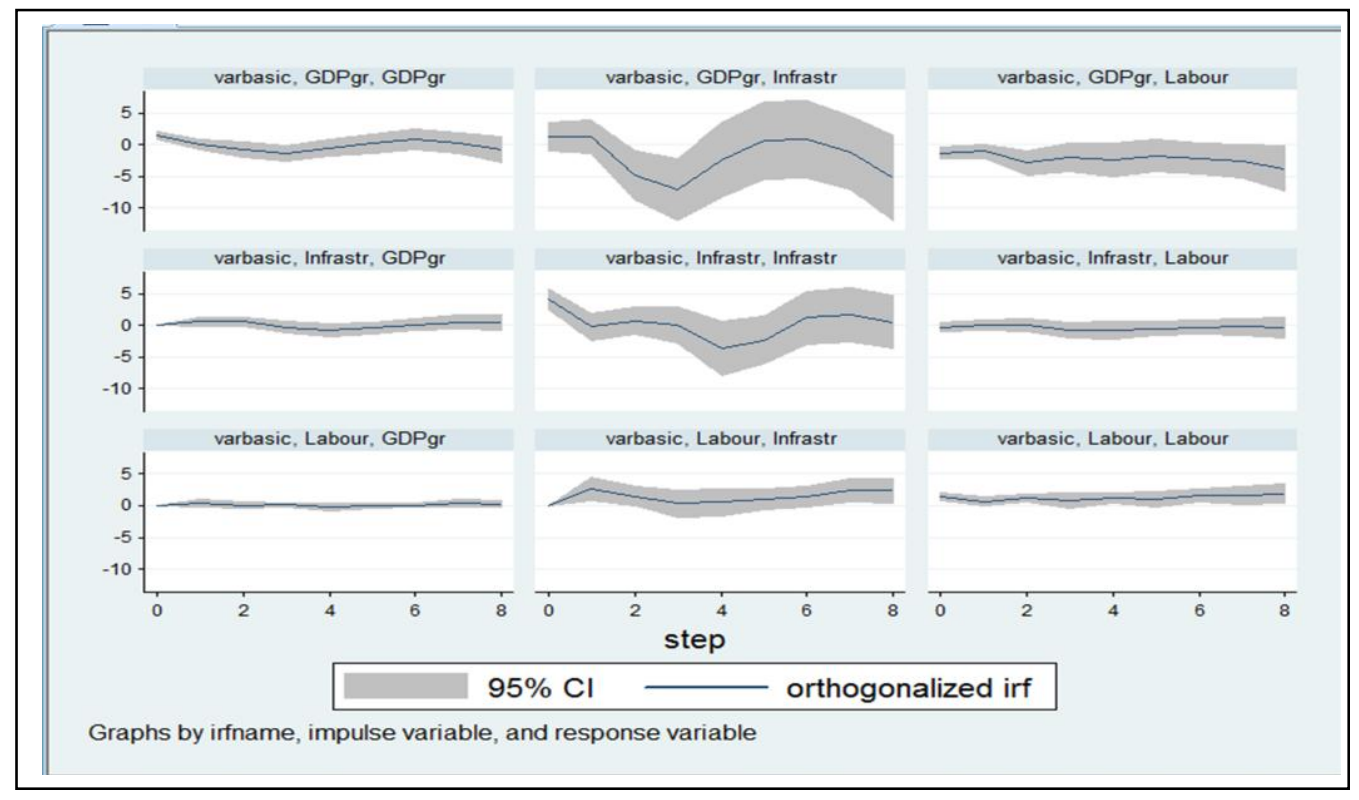

Figure 4. Impulse Response Functions' Graphs

Findings, Figure 4, show that infrastructure development significantly responded to shocks from economic growth even beyond eight years. Thus innovations in economic growth are vital in explaining the level of infrastructure in the country. The other notable finding is that shocks to infrastructure in the previous period would help explain its future behavior. This means what the government would spend in the current period is important in estimating the amount of money to be spend on infrastructure in the coming eight (8) years and even beyond. Shocks to infrastructure have no effect on economic growth and economic growth experienced in the previous period would not explain future movements in the country's growth.

\section{Conclusions}

The main objective of this paper was to determine the direction of causality between economic growth and infrastructural development. The paper also tested whether or not shocks in one variable would explain the future movements in the other. Findings showed that there is bidirectional causality between economic growth and infrastructural development. The study also showed that innovations in economic growth were important in explaining the behavior of infrastructure even beyond eight years. Infrastructure in the previous period explained its own movements in the later years. Findings show that economic growth in Kenya is driven by good quality as well as sufficient infrastructural expenditure. This means infrastructure led growth is important for Kenya. This is in support of President Uhuru Kenyata's policy direction of anchoring the Kenyan growth on infrastructural development. The findings also show that the growth in infrastructure will have feedback effects and fuel economic growth. It is against this background that the government needs to develop good quality and sufficient infrastructure to create a good platform for growth of the Kenyan economy. This is possible where the government also creates effective institutions to complement the better infrastructure since the later cannot be effective on its own. This is possible where the government focus on improving roads, provision of electricity, ports and railway networks. This means that authorities in Kenya can commit more funds towards developing infrastructure and labor at least in the short run in order to grow the economy. The quality of regulation also matters to help firms to realize the benefits of improved infrastructure. However there is still need for further research work on the contribution of quality of institutions and regulation on rate of growth for the economy.

\section{References}

African Development Bank Group. (2014). Kenya:Country Strategy Paper 2014-2018: EARC. Retrieved from: http://www.afdb.org/en/ (Accessed 20 February 2016). 
African Development Bank. (2013). The Africa Infrastructure Development Index (AIDI): African Development Bank Group. Retrieved from: http://www.afdb.org/en/ (Accessed 28 February 2016).

Ahmed, V., Abbas, A., \& Ahmed, S. (2013). Public Infrastructure and economic growth in Pakistan: A dynamic CGE microsimulation analysis. Partnership economic policy, Working Paper, http://dx.doi.org/10.1007/978-3-319-03137-8_5

Ansari, M. I., Gordon, D, V., \& Akuamoah, C. (2010). Keynes versus Wagner: public expenditure and national income for the three African countries. Applied Economics, 29(4), 543-550. http://dx.doi.org/10.1080/000368497327038

Aschauer, D. (1989). Is public Expenditure Productive? Journal of Monetary Economics, 23, 177-200. http://dx.doi.org/10.1016/0304-3932(89)90047-0

Babatunde, O, A., Afees, S, A., \& Olasunkanmi, U. I. (2012). Infrastructure and economic growth in Nigeria: A multivariate approach. Research Journal of Business Management and Accounting, 1(3), 30-39.

Banerjee, A., Duflo, E., \& Qian, N. (2012). On the road: Access to transportation infrastructure and economic growth in China. http://dx.doi.org/10.2139/ssrn.2018637

Barro, R. (1990). Government spending in a simple model of exogenous growth. Journal of Political Economy, 98, 103-125. http://dx.doi.org/10.1086/261726

Bom, P., \& Ligthart, J. (2009). How productive is public capital? A meta-regression analysis. Andrew School International Studies Program, Working Paper, 9-12.

Calderon, C., \& Serven, L. (2008). Infrastructure and economic development in Sub Saharan Africa. World Bank. http://dx.doi.org/10.1596/1813-9450-4712

Canning, D., \& Pedroni, P. (2004). The effects of infrastructure on Long run economic growth. Retrieved from: https://ideas.repec.org/p/wil/wileco/2004-04.html (Accessed 01 June 2016)

Congressional Budget Office .(2015). Public Spending on Transportation and Water Infrastructure, 1956 to 2014: Congress of the United States.

Ernst and Young Global Limited. (2014). Bridging the Gap: Ensuring Execution on Large Infrastructure Projects in Africa. Ernst and Young Global Limited

Estache, A., \& Garsous, G. (2012). The impact of infrastructure on growth in developing countries. IFC. Available at: http://www.ifc.org/wps/ (Accessed 15 May 2016)

Fedderke, J. W., Perkins, P., \& Luiz, J. M. (2006). Infrastructural investment in the long-run economic growth: South Africa 1875-2001. World development, 34, 1037-1059. http://dx.doi.org/10.1016/j.worlddev.2005.11.004

Fedderke, J., \& Garlick, R. (2008). Infrastructure development and economic growth in South Africa: A review of the accumulated evidence. University of Capetown, Policy paper No 12.

Green, W. (2012). Econometric Analysis. ( $7^{\text {th }}$ Ed). Pearson Education Limited. New York University

Gutman, J. S. A., \& Chattopadhyay, S. (2015). Financing African Infrastructure: Can the World Deliver?Global Economy and Development at Brookings. Retrieved from: http://www.brookings.edu/ (Accessed 10 March 2016)

Kaur, K., \& Malhotra, N. (2014). Telecommunications and economic growth in India: Causality analysis. International Journal of research in Business Management, 2(5), 31-46.

Kumo, W. L. (2012). Infrastructure investment and economic growth in South Africa: A granger causality analysis. Africa Development Bank group, Working paper series, 160.

Loayza, N., \& Odawara, R. (2010). Infrastructure and economic growth in Egypt Policy Research Working Paper: World Bank.

Lucas, R. (1988). On the mechanics of economic development. Journal of Monetary Economics, 22, 3-42. http://dx.doi.org/10.1016/0304-3932(88)90168-7

Nedozi, F. O., Obasanmi, J. O., \& Ighata, J. A. (2014). Infrastructural development and economic growth in Nigeria: Using Simultaneous equation. Journal of economics, 5(3), 325-332.

Owolabi, M. O. (2015). Infrastructure development and economic growth Nexus in Nigeria. International Journal of Academic Research in Business and Social Sciences 5(1), 376-382.http://dx.doi.org/10.6007/IJARBSS/v5-i1/1439

Romer, D., Weil, D. N., \& Mankiw, G. N. (1992). A contribution to the empirics of economic growth. The Quarterly Journal of Economics, 107(2), 407-437. http://dx.doi.org/10.2307/2118477 
Sahin, O., Can, N., \& Demirbas, E. (2014). The effects of infrastructure determinants on Economic growth: European Union sample. Eurasian Journal of business and economics, 7(13), 11-27.

Sahoo, P., \& Dash, K, R. (2009). Infrastructure development and economic growth in India. Journal of the Asia Pacific Economy, 14(4), 351-365. http://dx.doi.org/10.1080/13547860903169340

Sahoo, P., Dash, R. K., \& Nataraj, G. (2010). Infrastructure development and economic growth in China. IDE discussion paper, 261.

Serven, L. (2010). Infrastructure and Growth. World Bank: Development Research

Shiu, A., \& Lam, P. L. (2004). Electricity consumption and economic growth in China. Energy Policy, 32, 42-54. http://dx.doi.org/10.1016/s0301-4215(02)00250-1

Srinivasu, B., \& Rao, P, S. (2013). Infrastructure development and economic growth: Prospects and perspective. Journal of business management and Social sciences research, 2(1), 81-91.

Stewart, J. (2010). The UK National Infrastructure Plan 2010. European Investment Bank Papers: Public and Private Financing of Infrastructure.

Sutherland, D., Koźluk, T., \& Égert, B. (2009). Infrastructure and Growth: Empirical Evidence. Organization for Economic Cooperation and Development- Economics Department Working Paper. http://dx.doi.org/10.1787/225678178357

World Bank. (2011). East Africa's Infrastructure: A Continental Perspective. Policy Research Working Paper 5844

World Bank. (2013). Doing Business Survey. Retrieved from: http://www.worldbank.org (Accessed 01 February 2016)

World Bank. (2014). World Bank Data. Retrieved from: http://www.worldbank.org (Accessed 11 March 2016)

World Economic Forum. (2012). The Global Competitiveness Report 2012-2013. New York: WEF.

\section{(c) $\mathbf{E Y}$}

This work is licensed under a Creative Commons Attribution 3.0 License. 